\title{
Further snag with Stanford patent
}

Filing error claimed in Cohen-Boyer

\section{Washington}

The second Cohen-Boyer patent covering basic processes in genetic engineering may have suffered another setback last week when attorneys for the applicants admitted that there is a serious error in the patent specifications.

The error was one of several potential flaws cited by the US Patent and Trademark Office when, in August, it suddenly reversed its previous decision and decided to reject the patent (see Nature 12 August, p.595). Responding just one day before a deadline of 2 November, Stanford University and the University of California concede the error, but argue that the patent is nonetheless valid.

Their response, however, may raise more questions than it answers. Attorney Bertram Rowland, representing the universities, does not explain why he failed to inform the patent office of the error, which, he admits, "was known to the applicants' attorney as early as December 1977'. And the two lines of defence he introduces in support of the patent's validity may well be disputed.

Rowland argues that despite the error, the patent office should withdraw its

Rowland's concession concerns an article published in November 1977 by co-inventor Stanley Cohen and a coworker (Cohen, S.N. \& Chang, A.C.Y. J. Bact. 132, 734; 1977) which contradicts the recipe set out in the patent for making pSC101, the key plasmid used for inserting foreign DNA into Escherichia coli. "pSC101 could not be prepared in accordance with the working example", Rowland writes.

The Journal of Bacteriology article came to the attention of the patent office only this summer, apparently through an article by an Exxon patent attorney, Albert Halluin. In several footnotes to a chapter he contributed to The Patenting of Life Forms, a book published in August by Cold Spring Harbor Laboratory, Halluin cites that article and other potential flaws in the patent. Rowland, after admitting that he knew of the existence of Cohen's article five years ago, writes that " I have no recollection as to why it was not brought to the Examiner's attention in the written record"'. The patent application was filed on 4 November 1974; it was later split into two parts, and the first patent was granted on 2 December 1980.

objections and grant the patent, and he offers two lines of defence for that argument. The first is that even "if applicants had not actually performed any of the experiments described in the experimental section . . . the specification would be enabling (sufficient to allow duplication and thus be patentable), since it teaches how to obtain and clone a functional plasmid containing foreign DNA". In other words, pSC101 is not itself vital, as the instructions provided in the patent explain how to select, isolate and use other suitable plasmids. "Testimonials" from molecular biologists Donald Helinski, Stanley Falkow and Bernard Weisblum are included to buttress the claim that anyone with "ordinary skill" in the field could, since 4 November 1974 , have used the patent to prepare a functional plasmid - even without the benefit of a correct recipe for pSC101.

Yet in a submission to the patent office on 24 June 1977, Rowland seemed to take the opposite view - that pSC101 was indeed vital to the patent claims, and that this "new plasmid found by the inventors" was what distinguished their claims from potentially competing work by others.

The second line of defence offered by Rowland is that even if pSC101 is the key, the patent does not need to disclose how to make it since pSC101 was publicly

\section{UK research councils' budget break}

British research councils were told this week how much money they will get next year, but not which council is getting what - surely a formula for a scrap until the detailed allocations are announced in a few weeks' time.

According to Sir Keith Joseph, UK Secretary of State for Education and Science, who made a statement to the House of Commons on Monday, the total to be made available is $£ 509.7$ million, a shade above the $£ 507$ million requested by the Advisory Board for the Research Councils $(\mathrm{ABRC})$ a few weeks ago (see Nature 4 November, p.7) However, the new figure includes a Falklands factor - an extra $£ 4$ million for the British Antarctic Survey (BAS), in line with policy announced after the Falklands conflict to increase research in the Antarctic. BAS is a component institute of the Natural Environment Research Council (NERC). NERC would welcome the sum as a gift, a spokesman said this week, but would be worricd if it were to be subtracted from its planned budget for other science, or from that of other research councils.

Another unresolved issue is the position of the Agricultural Research Council, which has protested against ABRC's recommendation to hold its budget constant in cash terms for the next three available at the filing date. A declaration by Cohen, included in the response, states that he made the plasmid available to scientists, subject to two restrictions: "that it would not be passed on; that it should not be used in experiments believed at the time to have the potential to be dangerous". Cohen asserts that "no-one who requested pSC101 was denied pSC101"' and that it was thus "widely available".

One patent attorney familiar with the case said that Cohen's restrictions on distribution of the plasmid may defeat this defence; to be safe, he should have deposited the plasmid in a recognized public repository such as the American Type Culture Collection before filing. This was not done until 25 June 1981, six months after the first patent was granted.

Rowland's admission of the error in the second patent application raises a potentially explosive question: should the first patent, which contains the same flaw, be reissued to correct it? Given the problems with the second patent, this is something Stanford would like to avoid. In an interview last week, Rowland tried to avoid the issue, saying, "Given that 99 per cent or more of the people in the field are aware of the situation [the error in the pSC101 recipe], whether I should have to go to the expense of filing for reissuance is an open question". He added, "I don't

years at $£ 46$ million.

As for the Social Science Research Council, "a small portion" of the $£ 6$ million cut threatened recently by Sir Keith Joseph will fall this year, with more to come in the next two years. It will contribute to a $£ 14$ million fund to provide "the first instalment of a programme for new technologies, including the recruitment of young researchers". Of this, $£ 4$ million will go to establish courses in information technology in technical colleges and polytechnics. The remaining $£ 10$ million is for new blood as well as for the provision of courses in new technologies "primarily to improve the supply of manpower in information technology". Moreover, part of the sum will be allocated not by the University Grants Committee and the universities, but by the research councils, said Sir Keith. So it is impossible to determine exactly how many jobs this $£ 10$ million will make available. A separate announcement will give details.

As for the universities themselves, they will enjoy a small increase in their grant for the present academic year (1982-83) from $£ 1,137$ million to $£ 1,150$ million, and the recurrent grant for 1983-84 will be set at $£ 1,213$ million. These figures are fixed in cash terms, and assume a salary increase of only 3.5 per cent.

Robert Walgate 